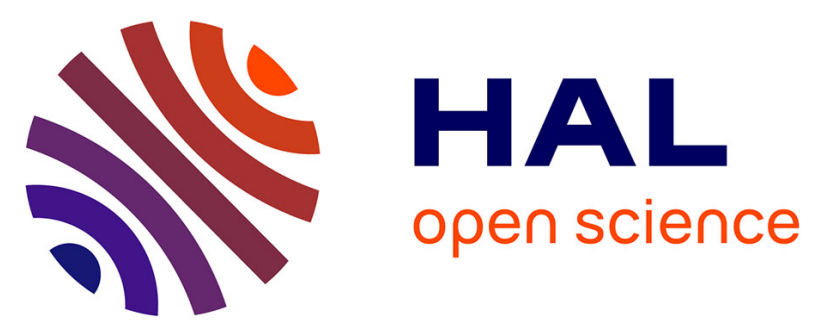

\title{
Maternal tobacco smoking in pregnancy and children's socio-emotional development at age 5: the EDEN mother-child birth cohort study
}

Maria Melchior, Robleh Hersi, Judith van Der Waerden, Béatrice Larroque, Marie-Josèphe Saurel-Cubizolles, Aude Chollet, Cédric Galéra

\section{To cite this version:}

Maria Melchior, Robleh Hersi, Judith van Der Waerden, Béatrice Larroque, Marie-Josèphe SaurelCubizolles, et al.. Maternal tobacco smoking in pregnancy and children's socio-emotional development at age 5: the EDEN mother-child birth cohort study. European Psychiatry, 2015, 30 (5), pp.562-568. 10.1016/j.eurpsy.2015.03.005 . hal-01142455

\section{HAL Id: hal-01142455 \\ https://hal.sorbonne-universite.fr/hal-01142455}

Submitted on 16 Apr 2015

HAL is a multi-disciplinary open access archive for the deposit and dissemination of scientific research documents, whether they are published or not. The documents may come from teaching and research institutions in France or abroad, or from public or private research centers.
L'archive ouverte pluridisciplinaire HAL, est destinée au dépôt et à la diffusion de documents scientifiques de niveau recherche, publiés ou non, émanant des établissements d'enseignement et de recherche français ou étrangers, des laboratoires publics ou privés. 
Maternal tobacco smoking and children's symptoms of hyperactivity/inattention_5_3_2015

Maternal tobacco smoking in pregnancy and children's socio-emotional development at age 5: the EDEN mother-child birth cohort study.

Maria Melchior ${ }^{1,2}$, Robleh Hersi ${ }^{1,2}$, Judith van der Waerden ${ }^{1,2}$, Béatrice Larroque $\ddagger^{3,4}$, Marie-Josèphe Saurel-Cubizolles ${ }^{3,4}$, Aude Chollet ${ }^{1,2}$, Cédric Galéra ${ }^{5,6}$ and the EDEN Mother-Child Cohort Study Group ${ }^{7}$

${ }^{1}$ Inserm, UMR_S 1136, Pierre Louis Institute of Epidemiology and Public Health, Department of Social Epidemiology, F-75013, Paris, France

2 Sorbonne Universités, UPMC Univ Paris 06, UMR-S 1136, Pierre Louis Institute of Epidemiology and Public Health, Department of Social Epidemiology, F-75013, Paris, France

3 INSERM, Obstetrical, Perinatal and Pediatric Epidemiology Research Team, Center for Epidemiology and Biostatistics (U1153), Paris-Descartes University, Paris, France

4 UPMC Univ Paris 06, UMR S 953, F-75005, Paris, France

5 Department of Child and Adolescent Psychiatry, Charles Perrens Hospital, University of Bordeaux, Bordeaux, France;

6 INSERM U897, Center for Research in Epidemiology and Biostatistics, Prévention et Prise en Charge des Traumatismes, Bordeaux, France

Corresponding author: Maria Melchior, Inserm, UMR_S 1136, Hôpital Paul Brousse, 16 avenue Paul Vaillant Couturier, 94800 Villejuif, maria.melchior@inserm.fr, +33(0)1 77747427.

No reprints used

Keywords : tobacco use, pregnancy, ADHD, cohort study

Word count: abstract: 249

text: 3082

\footnotetext{
${ }^{7}$ The EDEN Mother-Child Cohort Study Group: I. Annesi-Maesano, J. Botton, M.A. Charles, P. DargentMolina, B. de Lauzon-Guillain, P. Ducimetière, M. de Agostini, B. Foliguet, A. Forhan, X. Fritel, A. Germa, V. Goua, R. Hankard, B. Heude, M. Kaminski, B. Larroque, N. Lelong, J. Lepeule, G. Magnin, L. Marchand, C. Nabet, R. Slama, M.J. Saurel-Cubizolles, M. Schweitzer, O. Thiebaugeorge.
} 
Maternal tobacco smoking and children's symptoms of hyperactivity/inattention_5_3_2015

\section{Abstract}

Background: There is debate as to whether maternal tobacco use in pregnancy is related to offspring behavior later on. We tested this association examining multiple aspects of children's behavior at age 5 and accounting for parental smoking outside of pregnancy, as well as child and family characteristics.

Methods: Data come from a prospective community based birth cohort study (EDEN; $n=1,113$ families in France followed since pregnancy in 2003-2005 until the child's $5^{\text {th }}$ birthday). Maternal tobacco use in pregnancy was self-reported. Children's socio-emotional development (emotional symptoms, conduct problems, symptoms of hyperactivity/ inattention, peer relationship problems, prosocial behavior) was assessed by mothers using the Strengths and Difficulties Questionnaire (SDQ) at age 5 years. Logistic regression analyses controlled for Inverse Probability Weights (IPW) of maternal tobacco use calculated based on study center, children's characteristics (sex, premature birth, low birth weight, breastfeeding), maternal characteristics (age at the child's birth, psychological difficulties and alcohol use in pregnancy, post-pregnancy depression, and smoking), paternal smoking in and post pregnancy, parental educational attainment, family income, parental separation, and maternal negative life events.

Results: Maternal smoking in pregnancy only predicted children's high symptoms of hyperactivity/inattention (sex and study-center adjusted ORs: maternal smoking in the $1^{\text {st }}$ trimester: 1.95, 95\% $\mathrm{Cl}$ 1.13-3.38; maternal smoking throughout pregnancy: OR=2.11, 95\% $\mathrm{Cl}$ 1.36-3.27). In IPWcontrolled regression models, only children of mothers who smoked throughout pregnancy had significantly elevated levels of hyperactivity/inattention (OR=2.20, 95\% $\mathrm{Cl} 1.21-4.00$ ).

Conclusions: Maternal tobacco smoking in pregnancy may contribute directly or through epigenetic mechanisms to children's symptoms of hyperactivity/inattention.

Keywords: cigarette, ADHD symptoms, addiction, mental health 
Maternal tobacco smoking and children's symptoms of hyperactivity/inattention_5_3_2015

\section{Introduction}

Maternal tobacco use in pregnancy can have negative effects on children's birth characteristics and perinatal health (ex. increased risk of low birth weight and prematurity) [1, 2]. Moreover, children whose mothers smoke appear to have elevated levels of behavioral and substance-related problems [3-6]. In particular, research has consistently shown high rates of symptoms of hyperactivity/inattention and Attention Deficit and Hyperactivity Disorder (ADHD) [7-12]. The question of whether this association is causal has been widely debated [8] and findings from genetically informative studies suggest that this is probably not the case: rather, high levels of hyperactivity/inattention in children of smoking mothers could reflect the intergenerational transmission of a genetic vulnerability to behavioral difficulties or incomplete control for confounding factors such as socioeconomic position $[9,11,13]$.

Nonetheless, past research on this topic had several limitations. First, the extent of genetic confounding is yet uncertain. Studies conducted among siblings discordant with regard to maternal tobacco use show no effect of this exposure on children's behavior [10, 13], however these results could be biased due to sample selection and an uneven distribution of confounders across siblings [14]. In twin studies, estimates of heritability could be inflated because of gene $x$ environment interactions that are not entirely taken into account. Moreover, if genetic vulnerability plays a key role, one expects paternal tobacco smoking to be associated with children's behavior; however this is not always the case $[4,9,11,12,15]$. Additionally, the likelihood of symptoms of hyperactivity/inattention in the offspring should only moderately vary with the timing of maternal smoking (pre, during or post-pregnancy). Yet studies on this topic have reported elevated levels of behavioral problems only in children exposed to tobacco smoking in utero, including in historical times when maternal smoking in pregnancy was widespread [12]. Second, due to reliance on small samples $[7,9]$, merged datasets $[5,10]$ or data from birth registers [10], prior studies have not always accounted for all relevant covariates, particularly social and economic factors. Third, with rare exceptions [15], the specificity of the association between maternal smoking in pregnancy and 
Maternal tobacco smoking and children's symptoms of hyperactivity/inattention_5_3_2015 symptoms of hyperactivity/ inattention in the offspring has not been thoroughly studied [10].

Research primarily examined children's conduct problems or overall behavior [4] while a systematic comparison between different types of difficulties that children may experience could help make inferences about underlying mechanisms.

In the present study, using data from the French EDEN mother-child birth cohort study, we examine the hypothesis that maternal tobacco smoking in pregnancy is associated with children's behavior at age 5 years. To account for limitations of past research, we analyze the data: 1) using negative controls (paternal smoking), 2) comparing different time periods of exposure to maternal smoking (pre-, during and post-pregnancy), 3) comprehensively assessing children's social and family environment, 4) using inverse probability weights (IPWs) to account for covariates, and 5) studying multiple aspects of children's behavior.

\section{Methods}

\section{Study population}

The EDEN mother-child cohort study ('Etude sur les Déterminants pré et postnatals précoces du développement psychomoteur et de la santé de l'ENfant') aims to examine pre- and postnatal determinants of child growth, development and health. Pregnant women were recruited in two French university hospitals (Nancy and Poitiers, 2003-2005) before 24 weeks of gestation. Exclusion criteria were: multiple pregnancies, pre-pregnancy diabetes, illiteracy, and planned move outside the region in the following 3 years. 2,002 women were initially included during pregnancy and 1,893 agreed to have their newborns take part in the study. Average age, proportion of unmarried couples, and of children born with low birth weight in the EDEN study were comparable to national estimates, but maternal educational level was somewhat higher [16]. Over the follow-up period, attrition rates were highest in families in which the mother was young, had low educational level and low income, did not live with the child's father, smoked tobacco or had psychological difficulties in pregnancy, and whose child did not have low birth weight. 
Maternal tobacco smoking and children's symptoms of hyperactivity/inattention_5_3_2015

Since study inception, there have been eight waves of data collection (pregnancy, the child's birth, 4,

$8,12,24,36$ months and 5 years). Data were collected by trained interviewers (pregnancy, birth, 36 months), by mothers' and fathers' self-reports at all study waves, and from medical records (pregnancy, birth).

The EDEN cohort received approval from the Bicêtre Hospital ethics committee (CCPPRB) and the Commission Nationale Informatique et Libertés (CNIL) overseeing ethical data collection in France.

\section{$\underline{\text { Measures }}$}

\section{Maternal tobacco smoking}

Mothers reported on their tobacco smoking before and during pregnancy on the initial EDEN study questionnaire at 24-28 weeks of gestation ('Did you smoke in the three months prior to pregnancy?', 'Did you smoke in the first trimester of pregnancy?', 'Do you smoke now, and if yes how many cigarettes per day?') and once the child was born ('Did you smoke prior to pregnancy?', 'Did you smoke in the third trimester of pregnancy, and if yes how many cigarettes per day?', 'If you quit smoking during pregnancy, when did you quit?'). Based on this information, we created a fourcategory variable assessing maternal tobacco use: non-smoker (reference category), quit smoking prior to pregnancy, smoked in the first trimester of pregnancy (>=1 cigarette/day), smoked throughout pregnancy (>=1 cigarette/day). In additional analyses, we divided the group of mothers who quit smoking prior to pregnancy into two subgroups depending on whether they smoked during follow-up.

\section{Children's socio-emotional development}

Children's socio-emotional development was ascertained using the Strengths and Difficulties Questionnaire (SDQ) completed by the mothers when children were 5 years of age $[17,18]$. This validated instrument includes 25 items on 5 dimensions of children's behaviour: emotional symptoms, conduct problems, hyperactivity/inattention, peer relationship problems and prosocial 
Maternal tobacco smoking and children's symptoms of hyperactivity/inattention_5_3_2015 behaviour. Each item is scored 0 (never), 1 (sometimes true) or 2 (certainly true) and items composing each subscale are summed to generate a score ranging from 0 to 10 . Following prior research, children's scores on all SDQ subscales were dichotomized at the $85^{\text {th }}$ percentile, to study a high, potentially clinically significant, level of symptoms [19].

\section{Covariates}

Covariates included were all potentially associated with children's socio-emotional development: characteristics of parental smoking, characteristics of children, mothers and families measured at study baseline or longitudinally, that is combining all measures obtained across the eight waves of EDEN study follow-up.

Parental smoking, other than maternal tobacco use before and during pregnancy, was ascertained through maternal smoking post-pregnancy (yes vs. no), paternal smoking in pregnancy (yes vs. no), and paternal smoking post-pregnancy (yes vs. no).

Children's characteristics included the child's sex (male vs. female), premature ( $<37$ weeks gestation) birth (yes vs. no), birth weight (<=2500 vs. $>2500 \mathrm{~g}$ ) ascertained from the child's medical records, and duration of breastfeeding ( $<3$ vs. $>=3$ months) ascertained from maternal reports up to the child's 1 st birthday [20].

Maternal characteristics included age at the child's birth (<30 vs. $>=30$ years), psychological difficulties in pregnancy ascertained via high symptoms of depression measured with the CES-D (score $>=16$ )[21] and/or high anxiety measured with the STAI [22] (yes vs. no), maternal depression post-pregnancy measured with the EPDS at 4, 8, and 12 months post-partum [23] and with the CES-D at 36 months and 5 years [21] (yes vs. no), maternal alcohol use in pregnancy ( $>=1$ vs. $<1$ glass of alcohol/week).

Family characteristics included study center (Poitiers vs. Nancy), parents' educational attainment ascertained as highest of mother's and father's (< vs. >= any higher education), family income $(<1500$ vs. >=1500 euros/month, which corresponds to the lowest quartile of the distribution in our study population [24]), parental separation between pregnancy and the age 5 assessment (yes vs. no), 
Maternal tobacco smoking and children's symptoms of hyperactivity/inattention_5_3_2015 number of children in the family (>=1 vs. 0 ), and negative life events from pregnancy to the age 5 assessment : death of a close person, death of a child, home eviction, fire or other major damage to the home, serious parental health problems, parental unemployment, legal problems, maternal exposure to domestic or sexual violence (yes vs. no).

\section{$\underline{\text { Statistical analysis }}$}

Our aim was to examine the association between maternal tobacco smoking in pregnancy and children's behavioural difficulties. Analyses were based on the complete study sample from pregnancy to age 5 years $(n=1,113)$. First, we conducted logistic regression analyses adjusted for children's sex and study centre. Second, to control for factors which covary with maternal smoking in pregnancy and can bias the association with children's behaviour, we calculated Inverse Probability Weights (IPW) of exposure [25] based on all covariates potentially associated with our study outcome [26]. This method renders study groups comparable on all measured covariates, thereby mimicking the random allocation of exposure. Third, we conducted logistic regression analyses testing the association between maternal tobacco smoking in pregnancy and children's behaviour weighting the analysis on IPWs. Fourth, we tested the association between the average number of cigarettes smoked daily by the mother and children's behaviour. Fifth, we tested for interactions with the child's sex, parental educational attainment and income level. Sixth, we calculated the fraction of cases of high symptoms of hyperactivity/inattention potentially attributable to maternal smoking in pregnancy, using the following formula: Attributable Fraction=[OR-1]/[ $n^{\circ}$ exposed cases $/ n^{\circ}$ cases $][27]$. All analyses were conducted using SAS 9.2 (Carey, NC).

\section{Results}

Characteristics of EDEN cohort children and families according to maternal tobacco use in pregnancy are shown in Table 1. Overall, $7.8 \%$ of study mothers smoked only during the first trimester of pregnancy and $12.9 \%$ throughout pregnancy. $30.5 \%$ of mothers smoked post-pregnancy, while $36.0 \%$ of fathers smoked in pregnancy and $43.3 \%$ post-pregnancy. Factors associated with maternal tobacco 
Maternal tobacco smoking and children's symptoms of hyperactivity/inattention_5_3_2015 use in pregnancy include maternal smoking post-pregnancy $(p<0.0001)$, paternal smoking in pregnancy $(p<0.0001)$, paternal smoking post-pregnancy $(p<0.0001)$, duration of breastfeeding $(p<0.0001)$, maternal age $(p<0.0001)$, maternal psychological difficulties $(p=0.0006)$, maternal depression post-pregnancy $(p=0.04)$, maternal alcohol use $(p<0.0001)$, study center $(p=0.0006)$, parents' educational attainment $(p<0.0001)$, family income $(p<0.0001)$, parental separation $(p=0.0003)$ and negative life events $(p=0.0007)$.

Table 2 shows associations between maternal smoking in pregnancy and children's behaviour at age 5, controlling for children's sex and study centre. Maternal smoking in pregnancy was only associated with children's symptoms of hyperactivity/inattention (tobacco smoking during the 1st trimester of pregnancy: $\mathrm{OR}=1.95,95 \% \mathrm{Cl} 1.13-3.38$; tobacco smoking throughout pregnancy: $\mathrm{OR}=2.11,95 \% \mathrm{Cl} 1.36-3.27)$.

Table 3 shows associations between all potential covariates and children's symptoms of hyperactivity/inattention.

Table 4 shows IPW-controlled associations between maternal tobacco smoking in pregnancy and children's symptoms of hyperactivity/inattention. The OR associated with maternal smoking during the $1^{\text {st }}$ trimester of pregnancy was reduced compared to the sex and study center-adjusted model and became statistically non-significant ( $\mathrm{OR}=1.25,95 \% \mathrm{Cl} 0.58-2.68)$. However, the $\mathrm{OR}$ associated with maternal tobacco smoking throughout pregnancy was marginally higher and remained statistically significant (OR=2.20, 95\% Cl 1.21-4.00).

In additional analyses, we observed a dose-response association between maternal tobacco smoking and children's levels of hyperactivity/inattention, however, due to a small sample size, the ORs associated with different levels of maternal smoking were not statistically significant (1-9 cigarettes/ day: IPW-adjusted OR=1.49, 95\% Cl 0.52-4.21; >=10 cigarettes/ day: IPW-adjusted $\mathrm{OR}=1.64,0.53-4.64)$. The association between maternal smoking and children's symptoms of hyperactivity/ inattention did not vary with the child's sex, parental educational attainment or family 
Maternal tobacco smoking and children's symptoms of hyperactivity/inattention_5_3_2015 income. Overall, approximately $13 \%$ of cases of high symptoms of hyperactivity/inattention in children were potentially attributable to maternal smoking in pregnancy.

\section{Discussion}

Our findings suggest that maternal smoking during pregnancy may specifically contribute to symptoms of hyperactivity/inattention in children, which differs from the results of studies conducted among siblings $[10,13]$ or among children born using assisted reproduction technologies [9]. However, these genetically-informative designs may suffer from bias due to participants' selection and the uneven distribution of confounders among the exposed and the non-exposed [14], thus the jury is still out on the nature of the association between maternal tobacco use in pregnancy and children's behavior [28]. In the present study, we found a unique association between maternal smoking in pregnancy and children's behaviour, even after accounting for maternal smoking postpregnancy, paternal smoking and multiple characteristics of children and their families using the propensity score technique which is more robust than traditional methods to control for covariates. Our study contributes to research suggesting that maternal smoking during pregnancy may directly influence the likelihood of symptoms of hyperactivity/inattention in the offspring.

\section{$\underline{\text { Strengths and limitations }}$}

Key strengths of our study are: 1) a large size community based sample with prospective follow-up; 2 ) repeated assessments of multiple characteristics of children and their families from pregnancy to age $5 ; 3)$ the use of propensity scores - a statistical method designed to account for confounding as well as selection effects. Nevertheless, we also need to acknowledge limitations. First, families who did not take part in the follow-up were more likely to experience socioeconomic difficulties, therefore the relationship between maternal smoking in pregnancy and children's behaviour may be underestimated. Second, symptoms of hyperactivity/inattention were reported by children's mothers and could suffer from information bias [29]. Maternal reports of high levels of hyperactivity/inattention are probably valid; nonetheless, future studies should aim to use multiple 
Maternal tobacco smoking and children's symptoms of hyperactivity/inattention_5_3_2015 sources of information (ex. mother, father or teacher, and child him/herself) [30] or study clinical diagnoses of ADHD. Third, tobacco use in pregnancy was ascertained by the mothers and could be underreported, which again would bias our results towards the null. Future studies should consider ascertaining maternal tobacco use through questionnaires as well as biological measures. Fourth, we did not assess potential confounders such as paternal psychopathology, use of substances other than tobacco and genetic/biological factors; the inclusion of these elements in future investigations can help disentangle the complex processes implicated in the etiology of hyperactivity/inattention.

\section{$\underline{\text { Putative mechanisms }}$}

The association between maternal tobacco smoking in pregnancy and children's symptoms of hyperactivity/inattention may reflect several mechanisms. First, mothers who do not quit smoking in pregnancy probably have especially high levels of nicotine dependence and can transmit this heightened vulnerability to addiction and behavioral difficulties to their children [31]. We found no association between paternal smoking and children's behavior, which goes against the hypothesis of genetic confounding, yet fathers are much less likely than mothers to reduce tobacco use before a child's birth and genetic factors may play a lesser role with regard to paternal than maternal smoking. Second, maternal smoking in pregnancy may be a marker of environmental confounding by factors such as maternal psychological difficulties related both to a decreased ability to quit smoking (despite warnings and known fetus toxicity) and less positive parenting after the child's birth. For example, high levels of maternal smoking in pregnancy have been associated with mothers' reduced feelings of attachment towards the fetus [32] and worse mother-child attachment in infancy [33]. This lower quality of mother-child attachment could in turn contribute to later ADHD symptoms [34]. A recent review [35] reports that compared to persistent smokers, women who spontaneously quit during pregnancy show a more secure pattern of attachment to their infant and higher levels of parenting competence, implying that the ability to quit smoking may in part reflect the mother's investment in her pregnancy and child. Failure in quitting appears to be associated with maternal conduct disorder but not ADHD, again going against the hypothesis that the association between maternal tobacco 
Maternal tobacco smoking and children's symptoms of hyperactivity/inattention_5_3_2015 smoking and children's symptoms of hyperactivity/inattention is solely due to genetic factors. Third, maternal tobacco smoking may have direct teratological effects on fetal brain development in utero and immediately after birth $[36,37]$. These effects could occur through the impact of tobacco on cerebral structures and connectivity, neurotransmission, as well as neuronal differentiation and migration [37-39]. In addition, tobacco products and nicotine could impair placental function, resulting in chronic fetal hypoxia and subsequent fetal growth retardation $[40,41]$. Fourth, growing evidence suggests that prenatal tobacco smoking may have epigenetic effects both on fetal and placental tissues [42-44].

\section{$\underline{\text { Implications }}$}

Tobacco smoking during pregnancy is one of the most common and preventable risk factors of poor pregnancy and infant outcomes. Quitting smoking has many health benefits for the mother and her child. Importantly, our findings suggest that smoking in the first trimester only is not associated with children's behavioral difficulties, underlining the potential benefits of smoking cessation during the course of pregnancy. However, it is still possible that smoking during pregnancy is a marker of biological or psychological risk which is transmitted intergenerationally. This implies that health professionals should screen for these factors in women who do not quit smoking during pregnancy in order to provide adequate support, potentially targeting characteristics such as insecure attachment, parenting difficulties, maternal conduct disorder, or parental substance use disorders. Early action on these characteristics could positively influence a range of outcomes in the offspring among which symptoms of ADHD. As suggested by Massey et al. [35], among pregnant women who smoke tobacco, efforts could be dedicated not only to smoking cessation but also to the development of psychoeducational and parenting interventions. We are not able to entirely reject the possibility that genetic factors play a role in this association, either directly or via epigenetic processes, nonetheless, maternal smoking in pregnancy may also have effects on children's behavior, through physiological mechanisms which are not yet fully uncovered. Future etiological research on the causes of ADHD, 
Maternal tobacco smoking and children's symptoms of hyperactivity/inattention_5_3_2015

should integrate measures of early environmental, biological, psychological and social processes

provided to the child by the mother and her surroundings.

\section{Conclusions}

Maternal tobacco smoking in pregnancy may contribute directly or through epigenetic mechanisms to children's symptoms of hyperactivity/inattention. 
Maternal tobacco smoking and children's symptoms of hyperactivity/inattention_5_3_2015

\section{Funding and other support}

The authors thank the EDEN study team for help in implementing the study. This work was supported by: Fondation pour la Recherche Médicale (FRM); French Ministry of Research: IFR Program; INSERM Human Nutrition National Research Program; Diabetes National Research Program (through a collaboration with the French Association of Diabetic Patients (AFD)); French Ministry of Health; French Agency for Environment Security (AFSSET); French National Institute for Population Health Surveillance (InVS); Paris-Sud University; French National Institute for Health Education (INPES); Nestlé; Mutuelle Générale de l'Education Nationale (MGEN); French speaking association for the study of diabetes and metabolism (ALFEDIAM); National Agency for Research (ANR nonthematic programme); and National Institute for Research in Public Health (IRESP: TGIR Cohorte Santé 2008 programme). Maria Melchior is the recipient of a Young Researcher Award from the French National Research Agency (ANR). The founders had no further role in study design; in the collection, analysis and interpretation of data; in the writing of the report; or in the decision to submit the paper for publication.

\section{Conflict of interest}

The authors declare no conflicts of interest. 
Maternal tobacco smoking and children's symptoms of hyperactivity/inattention_5_3_2015

References

(1) Andres RL, Day MC. Perinatal complications associated with maternal tobacco use. Sem Neonatol 2000;5:231-41.

(2) Iniguez C, Ballester F, Costa O, Murcia M, Souto A, Santa-Marina L, et al. Maternal smoking during pregnancy and fetal biometry: the INMA Mother and Child Cohort Study. Am J Epidemiol 2013;178:1067-75.

(3) Ernst M, Moolchan ET, Robinson ML. Behavioral and neural consequences of prenatal exposure to nicotine. J Am Acad Child Adolesc Psychiatry 2001;40:630-41.

(4) Roza SJ, Verhulst FC, Jaddoe VW, Steegers EA, Mackenbach JP, Hofman A, et al. Maternal smoking during pregnancy and child behaviour problems: the Generation R Study. Int J Epidemiol 2009;38:680-9.

(5) Gaysina D, Fergusson DM, Leve LD, Horwood J, Reiss D, Shaw DS, et al. Maternal Smoking During Pregnancy and Offspring Conduct Problems: Evidence From 3 Independent Genetically Sensitive Research Designs. JAMA Psychiatry 2013;70:956-63.

(6) Hellstrom-Lindahl E, Nordberg A. Smoking during pregnancy: a way to transfer the addiction to the next generation? Respiration 2002;69:289-93.

(7) Linnet KM, Wisborg K, Obel C, Secher NJ, Thomsen PH, Agerbo E, et al. Smoking during pregnancy and the risk for hyperkinetic disorder in offspring. Pediatrics 2005;116:462-7.

(8) Thapar A, Rutter M. Do prenatal risk factors cause psychiatric disorder? Be wary of causal claims. Br J Psychiatry 2009;195:100-1.

(9) Thapar A, Rice F, Hay D, Boivin J, Langley K, van den Bree M, et al. Prenatal smoking might not cause attention-deficit/hyperactivity disorder: evidence from a novel design. Biol Psychiatry 2009;66:722-7.

(10) Obel C, Olsen J, Henriksen TB, Rodriguez A, Jarvelin MR, Moilanen I, et al. Is maternal smoking during pregnancy a risk factor for hyperkinetic disorder?--Findings from a sibling design. Int J Epidemiol 2011;40:338-45.

(11) Langley K, Heron J, Smith GD, Thapar A. Maternal and paternal smoking during pregnancy and risk of ADHD symptoms in offspring: testing for intrauterine effects. Am J Epidemiol 2012;176:261-8.

(12) Keyes KM, Davey SG, Susser E. Associations of prenatal maternal smoking with offspring hyperactivity: causal or confounded? Psychol Med 2014;44: 857-867.

(13) Skoglund C, Chen Q, D'Onofrio BM, Lichtenstein P, Larsson H. Familial confounding of the association between maternal smoking during pregnancy and ADHD in offspring. J Child Psychol Psychiatry 2014;55:61-8.

(14) Frisell T, Oberg S, Kuja-Halkola R, Sjolander A. Sibling comparison designs: bias from nonshared confounders and measurement error. Epidemiol 2012;23:713-20. 
Maternal tobacco smoking and children's symptoms of hyperactivity/inattention_5_3_2015

(15) Brion MJ, Victora C, Matijasevich A, Horta B, Anselmi L, Steer C, et al. Maternal smoking and child psychological problems: disentangling causal and noncausal effects. Pediatrics 2010;126:e57-e65.

(16) Blondel B, Lelong N, Kermarrec M, Goffinet F. [Trends in perinatal health in France between 1995 and 2010: Results from the National Perinatal Surveys]. J Gynécol Obst Biol Reproduct 2012;41:151-66.

(17) Goodman R. The Strengths and Difficulties Questionnaire: a research note. J Child Psychol Psychiatry 1997;38:581-6.

(18) Marzocchi GM, Capron C, Di PM, Duran TE, Duyme M, Frigerio A, et al. The use of the Strengths and Difficulties Questionnaire (SDQ) in Southern European countries. Europ Child Adolesc Psychiatry 2004;13 Suppl 2:I140-II46.

(19) Amone-P'olak K, Burger H, Ormel J, Huisman M, Verhulst FC, Oldehinkel AJ. Socioeconomic position and mental health problems in pre- and early-adolescents : The TRAILS study. Soc Psychiatry Psychiatr Epidemiol 2009;44:231-8.

(20) Betoko A, Charles MA, Hankard R, Forhan A, Bonet M, Saurel-Cubizolles MJ, et al. Infant feeding patterns over the first year of life: influence of family characteristics. Europ J Clin Nutrition 2013;67:631-7.

(21) Radloff L. The CES-D scale : a self report depression scale for research in the general population. Appl Psychol Measur 1977;1:385-401.

(22) Spielberger C. State-Trait Anxiety Inventory (Form Y). Palo Alto, CA: Mind Garden; 1983.

(23) Cox JL, Chapman G, Murray D, Jones P. Validation of the Edinburgh Postnatal Depression Scale (EPDS) in non-postnatal women. J Affect Disord 1996;39:185-9.

(24) Melchior M, Chastang J-F, de Lauzon B, Galéra C, Saurel-Cubizolles M-J, Larroque B. Maternal depression, socioeconomic position, and temperament in early childhood: the EDEN motherchild cohort. J Affect Disord 2012;137:165-9.

(25) Hernan M, Robbins J. IP weighting and marginal structural models. Causal Inference. 2013. p. 11-21.

(26) Austin PC. An introduction to propensity score methods for reducing the effects of confounding in observational studies. Multivar Behav Res 2011;46:399-424.

(27) Hanley J. A heuristic approach to the formulas for population attributable fraction. J Epidemiol Community Health 2001;55:508-14.

(28) Keyes KM, Smith GD, Susser E. Commentary: Smoking in pregnancy and offspring health: early insights into family-based and 'negative control' studies? Int J Epidemiol 2014;43:13818.

(29) Weissman MM, Wickramaratne P, Warner V, John K, Prusoff BA, Merikangas KR, et al. Assessing psychiatric disorders in children. Discrepancies between mothers' and children's reports. Arch Gen Psychiatry 1987;44:747-53.

(30) Weiler MD, Bellinger D, Marmor J, Rancier S, Waber D. Mother and teacher reports of ADHD symptoms: DSM-IV Questionnaire data. J Am Acad Child Adolesc Psychiatry 1999;38:1139-47. 
Maternal tobacco smoking and children's symptoms of hyperactivity/inattention_5_3_2015

(31) McClernon FJ, Kollins SH. ADHD and smoking: from genes to brain to behavior. Annals of the New York Academy of Sciences 2008 Oct;1141:131-47.

(32) Magee SR, Bublitz MH, Orazine C, Brush B, Salisbury A, Niaura R, et al. The relationship between maternal-fetal attachment and cigarette smoking over pregnancy. Matern Child Health J 2014; 18: 1017-1022.

(33) Chittleborough CR, Lawlor DA, Lynch JW. Prenatal prediction of poor maternal and offspring outcomes: implications for selection into intensive parent support programs. Matern Child Health J 2012;16:909-20.

(34) Storebo OJ, Darling RP, Simonsen E. Association between insecure attachment and ADHD: environmental mediating factors. J Attention Disord 2013 In Press.

(35) Massey SH, Compton MT. Psychological differences between smokers who spontaneously quit during pregnancy and those who do not: a review of observational studies and directions for future research. Nicotine Tobacco Res 2013;15:307-19.

(36) Cornelius MD, Day NL. Developmental consequences of prenatal tobacco exposure. Current Opin Neurol 2009;22:121-5.

(37) Dwyer JB, McQuown SC, Leslie FM. The dynamic effects of nicotine on the developing brain. Pharmacol Therapeutics 2009;122:125-39.

(38) Bublitz MH, Stroud LR. Maternal smoking during pregnancy and offspring brain structure and function: review and agenda for future research. Nicotine Tobacco Res 2012;14:388-97.

(39) Heath CJ, King SL, Gotti C, Marks MJ, Picciotto MR. Cortico-thalamic connectivity is vulnerable to nicotine exposure during early postnatal development through alpha4/beta2/alpha5 nicotinic acetylcholine receptors. Neuropsychopharmacol 2010;35:2324-38.

(40) Herrmann M, King K, Weitzman M. Prenatal tobacco smoke and postnatal secondhand smoke exposure and child neurodevelopment. Current Opin Pediatrics 2008;20:184-90.

(41) Jauniaux E, Burton GJ. Morphological and biological effects of maternal exposure to tobacco smoke on the feto-placental unit. Early Human Develop 2007;83:699-706.

(42) Suter M, Abramovici A, Aagaard-Tillery K. Genetic and epigenetic influences associated with intrauterine growth restriction due to in utero tobacco exposure. Pediatr Endocrinol Rev 2010;8:94-102.

(43) Suter M, Ma J, Harris A, Patterson L, Brown KA, Shope C, et al. Maternal tobacco use modestly alters correlated epigenome-wide placental DNA methylation and gene expression. Epigenetics 2011;6:1284-94.

(44) Maccani MA, Avissar-Whiting M, Banister CE, McGonnigal B, Padbury JF, Marsit CJ. Maternal cigarette smoking during pregnancy is associated with downregulation of miR-16, miR-21, and miR-146a in the placenta. Epigenetics 2010;5:583-9. 
Maternal tobacco smoking and children's symptoms of hyperactivity/inattention_5_3_2015

Table 1. Characteristics of mothers and children participating in the EDEN mother-child birth cohort study according to maternal smoking in pregnancy $(n=1113, \%)$

\section{Maternal smoking in pregnancy}

\begin{tabular}{|c|c|c|c|c|}
\hline Parental tobacco smoking & $\begin{array}{c}\text { Non-smoker } \\
(n=777)\end{array}$ & \begin{tabular}{|} 
Quit smoking \\
prior to \\
pregnancy \\
(n=105)
\end{tabular} & $\begin{array}{c}\text { Smoked during } \\
\text { the } 1^{\text {st }} \text { trimester } \\
\text { of pregnancy } \\
(n=87)\end{array}$ & $\begin{array}{c}\text { Smoked } \\
\text { throughout } \\
\text { pregnancy } \\
(n=144)\end{array}$ \\
\hline \multirow{3}{*}{$\begin{array}{l}\text { Maternal smoking post pregnancy: } \\
\text { No } \\
\text { Mes } \\
\text { Missing data } n=11\end{array}$} & 91.7 & 31.4 & 29.1 & 3.5 \\
\hline & 8.3 & 68.6 & 70.9 & 96.5 \\
\hline & \multicolumn{4}{|c|}{$p<0.0001$} \\
\hline \multirow{3}{*}{$\begin{array}{l}\text { Paternal smoking in pregnancy: No } \\
\text { Missing data } n=74\end{array}$} & 74.8 & 50.0 & 41.0 & 27.9 \\
\hline & 25.2 & 50.0 & 59.0 & 72.1 \\
\hline & \multicolumn{4}{|c|}{$p<0.0001$} \\
\hline \multirow{3}{*}{ 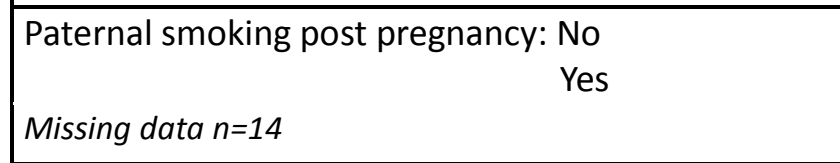 } & 68.4 & 35.0 & 37.2 & 20.0 \\
\hline & 31.6 & 65.1 & 62.8 & 80.0 \\
\hline & \multicolumn{4}{|c|}{$p<0.0001$} \\
\hline \multicolumn{5}{|l|}{ Children's characteristics } \\
\hline \multirow{3}{*}{$\begin{array}{l}\text { Sex : Female } \\
\text { Male } \\
\text { Missing data } n=0\end{array}$} & 46.6 & 48.6 & 48.3 & 47.9 \\
\hline & 53.4 & 51.4 & 51.7 & 52.1 \\
\hline & \multicolumn{4}{|c|}{$p=0.97$} \\
\hline \multirow{3}{*}{$\begin{array}{l}\begin{aligned} & \text { Born premature : } \text { No } \\
& \text { Yes } \\
& \text { Missing data } n=0\end{aligned}\end{array}$} & 94.0 & 93.3 & 97.7 & 95.8 \\
\hline & 6.1 & 6.7 & 2.3 & 4.2 \\
\hline & \multicolumn{4}{|c|}{$p=0.41$} \\
\hline \multirow{3}{*}{$\begin{aligned} \text { Birthweight }: & >2500 \mathrm{~g} \\
& <=2500 \mathrm{~g} \\
\text { Missing data } n & =0\end{aligned}$} & 95.4 & 95.2 & 95.4 & 94.4 \\
\hline & 4.6 & 4.8 & 4.6 & 5.6 \\
\hline & \multicolumn{4}{|c|}{$p=0.97$} \\
\hline \multirow{3}{*}{$\begin{aligned} \text { Duration of breastfeeding : } & >=3 \text { months } \\
& <3 \text { months } \\
\text { Missing data } n=0 & \end{aligned}$} & 60.4 & 57.1 & 50.6 & 40.3 \\
\hline & 39.6 & 42.9 & 49.4 & 59.7 \\
\hline & \multicolumn{4}{|c|}{$p<0.0001$} \\
\hline \multicolumn{5}{|l|}{ Maternal characteristics } \\
\hline \multirow{3}{*}{$\begin{array}{l}\text { Maternal age at child's birth } \begin{aligned} &:<30 \text { years } \\
&>=30 \text { years } \\
& \text { Missing data } n=0\end{aligned}\end{array}$} & 41.6 & 61.9 & 55.2 & 53.5 \\
\hline & 58.4 & 38.1 & 44.8 & 46.5 \\
\hline & \multicolumn{4}{|c|}{$p<0.0001$} \\
\hline \multirow{3}{*}{$\begin{array}{l}\text { Maternal psychological difficulties in pregnancy: No } \\
\text { Yes } \\
\text { Missing data } n=9\end{array}$} & 81.4 & 69.5 & 68.2 & 71.8 \\
\hline & 18.7 & 30.5 & 31.8 & 28.2 \\
\hline & \multicolumn{4}{|c|}{$p=0.0006$} \\
\hline \multirow{3}{*}{\begin{tabular}{|l} 
Maternal depression post pregnancy: \\
No \\
Missing data $n=0$ \\
\end{tabular}} & 80.1 & 77.1 & 71.3 & 70.8 \\
\hline & 20.0 & 22.9 & 28.7 & 29.2 \\
\hline & \multicolumn{4}{|c|}{$p=0.04$} \\
\hline \multirow{3}{*}{$\begin{array}{l}\text { Maternal alcohol use in pregnancy: } \begin{array}{l}<1 \text { glass/week } \\
>=1 \text { glass/week }\end{array} \\
\text { Missing data } n=274\end{array}$} & 83.1 & 75.0 & 60.9 & 69.7 \\
\hline & 17.0 & 25.0 & 39.1 & 30.3 \\
\hline & \multicolumn{4}{|c|}{$p<0.0001$} \\
\hline \multicolumn{5}{|l|}{ Family characteristics } \\
\hline \multirow{3}{*}{ 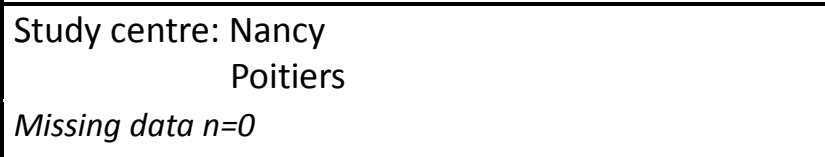 } & 48.8 & 59.1 & 42.5 & 34.0 \\
\hline & 51.2 & 41.0 & 57.5 & 66.0 \\
\hline & \multicolumn{4}{|c|}{$p=0.0006$} \\
\hline
\end{tabular}


Maternal tobacco smoking and children's symptoms of hyperactivity/inattention_5_3_2015

\begin{tabular}{|c|c|c|c|c|}
\hline \multirow{2}{*}{$\begin{array}{l}\begin{aligned} \text { Parents' educational attainment : } & >=\text { Higher education } \\
& <\text { Higher education }\end{aligned} \\
\text { Missing data } n=8\end{array}$} & $\begin{array}{l}72.5 \\
27.5\end{array}$ & $\begin{array}{l}69.9 \\
30.1\end{array}$ & $\begin{array}{l}62.1 \\
37.9\end{array}$ & $\begin{array}{l}46.1 \\
53.9\end{array}$ \\
\hline & \multicolumn{4}{|c|}{$p<0.0001$} \\
\hline \multirow{2}{*}{ 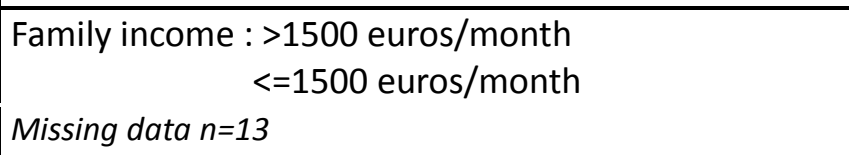 } & $\begin{array}{l}73.5 \\
26.5\end{array}$ & $\begin{array}{l}75.5 \\
24.5\end{array}$ & $\begin{array}{l}63.5 \\
36.5\end{array}$ & $\begin{array}{l}49.3 \\
50.7\end{array}$ \\
\hline & \multicolumn{4}{|c|}{$p<0.0001$} \\
\hline \multirow{2}{*}{$\begin{array}{l}\begin{array}{l}\text { Parental separation: No } \\
\text { Yes }\end{array} \\
\text { Missing data } n=19\end{array}$} & $\begin{array}{l}89.3 \\
10.7\end{array}$ & $\begin{array}{l}80.4 \\
19.6\end{array}$ & $\begin{array}{l}80.0 \\
20.0\end{array}$ & $\begin{array}{l}78.6 \\
21.4\end{array}$ \\
\hline & \multicolumn{4}{|c|}{$p=0.0003$} \\
\hline \multirow{2}{*}{$\begin{array}{l}\text { Number of siblings: None } \\
\qquad>=1 \\
\text { Missing data } n=0\end{array}$} & $\begin{array}{l}45.2 \\
54.8\end{array}$ & $\begin{array}{l}54.3 \\
45.7\end{array}$ & $\begin{array}{l}54.0 \\
46.0\end{array}$ & $\begin{array}{l}53.5 \\
46.5\end{array}$ \\
\hline & \multicolumn{4}{|c|}{$p=0.07$} \\
\hline \multirow{2}{*}{$\begin{array}{l}\begin{array}{l}\text { Negative life events: } \\
\text { Yes } \\
\text { Missing data } n=2\end{array} \\
\end{array}$} & $\begin{array}{l}45.7 \\
54.3\end{array}$ & $\begin{array}{l}44.8 \\
55.2\end{array}$ & $\begin{array}{l}39.1 \\
60.9\end{array}$ & $\begin{array}{l}27.5 \\
72.5\end{array}$ \\
\hline & \multicolumn{4}{|c|}{$p=0.0007$} \\
\hline
\end{tabular}


Table 2. Maternal tobacco smoking in pregnancy and children's emotional and behavioral symptoms at age 5 years (EDEN mother-child birth cohort study, $\mathrm{n}=1113$, logistic regression models adjusted for children's sex and study center, OR, 95\% Cl)

\begin{tabular}{|c|c|c|c|c|c|}
\hline & $\begin{array}{l}\text { High emotional } \\
\text { symptoms } \\
(238 / 1113)\end{array}$ & $\begin{array}{l}\text { High conduct problems } \\
(174 / 1112)\end{array}$ & $\begin{array}{l}\text { High symptoms of } \\
\text { hyperactivity/ } \\
\text { Inattention } \\
\text { (176/1113) }\end{array}$ & $\begin{array}{c}\text { High peer relationship } \\
\text { problems } \\
(160 / 1112)\end{array}$ & $\begin{array}{l}\text { Low prosocial } \\
\text { behavior } \\
(365 / 1110)\end{array}$ \\
\hline $\begin{array}{l}\text { Maternal tobacco smoking in pregnancy } \\
\text { Non-smoker }(n=777)\end{array}$ & 1 & 1 & 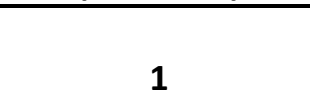 & 1 & 1 \\
\hline Quit smoking prior to pregnancy $(n=105)$ & $1.05(0.63-1.73)$ & $0.95(0.53-1.70)$ & $1.35(0.76-2.37)$ & $1.13(0.64-2.00)$ & $0.86(0.55-1.34)$ \\
\hline Smoked in the 1 st trimester of pregnancy $(n=87)$ & $1.41(0.85-2.34)$ & $1.36(0.76-2.43)$ & $1.95(1.13-3.38)$ & $1.33(0.73-2.41)$ & $0.98(0.61-1.58)$ \\
\hline Smoked throughout pregnancy $(n=144)$ & $1.25(0.82-1.90)$ & $1.56(0.99-2.48)$ & $2.11(1.36-3.27)$ & $1.22(0.75-2.00)$ & $0.77(0.52-1.15)$ \\
\hline
\end{tabular}


Table 3. Characteristics of mothers and children participating in the EDEN mother-child birth cohort study in relation to high symptoms of hyperactivity/inattention ( $n=1113,0 R, 95 \% \mathrm{Cl})$

\begin{tabular}{|c|c|c|}
\hline & $N$ & ORs, $95 \% \mathrm{Cl}, p$-value \\
\hline $\begin{array}{l}\text { Parental tobacco smoking } \\
\text { Maternal tobacco smoking post pregnancy: No } \\
\text { Yes }\end{array}$ & 1102 & $\begin{array}{c}1 \\
1.68(1.20-2.34)\end{array}$ \\
\hline $\begin{aligned} \text { Paternal tobacco smoking in pregnancy: } & \text { No } \\
& \text { Yes } \\
& \text { Not known }\end{aligned}$ & 1113 & $\begin{array}{c}1 \\
1.28(0.68-2.42) \\
1.33(0.95-1.88)\end{array}$ \\
\hline $\begin{array}{r}\text { Paternal tobacco smoking post pregnancy: No } \\
\text { Yes }\end{array}$ & 1099 & $\begin{array}{c}1 \\
1.17(0.84-1.62)\end{array}$ \\
\hline $\begin{array}{l}\text { Children's characteristics } \\
\text { Sex : Female } \\
\quad \text { Male }\end{array}$ & 1113 & $\begin{array}{c}1 \\
1.95(1.39-2.74)\end{array}$ \\
\hline $\begin{array}{r}\text { Born premature : No } \\
\text { Yes }\end{array}$ & 1113 & $\begin{array}{c}1 \\
1.03(0.51-2.06)\end{array}$ \\
\hline $\begin{aligned} & \text { Birthweight : }>2500 \mathrm{~g} \\
&<=2500 \mathrm{~g} \\
&\end{aligned}$ & 1113 & $\begin{array}{c}1 \\
1.09(0.52-2.28) \\
\end{array}$ \\
\hline $\begin{aligned} \text { Duration of breastfeeding : } & >=3 \text { months } \\
& <3 \text { months }\end{aligned}$ & 1113 & $\begin{array}{c}1 \\
1.67(1.21-2.30) \\
\end{array}$ \\
\hline $\begin{array}{l}\text { Maternal characteristics } \\
\text { Maternal age at child's birth }:<30 \text { years } \\
\qquad>=30 \text { years }\end{array}$ & 1113 & $\begin{array}{c}1 \\
0.60(0.43-0.83)\end{array}$ \\
\hline $\begin{array}{r}\text { Maternal psychological difficulties in pregnancy: No } \\
\text { Yes }\end{array}$ & 1104 & $\begin{array}{c}1 \\
1.69(1.18-2.42)\end{array}$ \\
\hline $\begin{array}{c}\text { Maternal depression post pregnancy: No } \\
\text { Yes } \\
\end{array}$ & 1113 & $\begin{array}{c}1 \\
1.84(1.29-2.62) \\
\end{array}$ \\
\hline $\begin{aligned} \text { Maternal alcohol use in pregnancy: } & <1 \text { glass/week } \\
& >=1 \text { glass/week } \\
& \text { No information }\end{aligned}$ & 1113 & $\begin{array}{c}1 \\
1.25(0.81-1.93) \\
1.00(0.68-1.48) \\
\end{array}$ \\
\hline $\begin{array}{l}\text { Family characteristics } \\
\text { Study center: Nancy } \\
\text { Poitiers } \\
\end{array}$ & 1113 & $\begin{array}{c}1 \\
1.66(1.19-2.32)\end{array}$ \\
\hline $\begin{aligned} \text { Parents' educational attainment : } & >=\text { Higher education } \\
& <\text { Higher education }\end{aligned}$ & 1105 & $\begin{array}{c}1 \\
2.06(1.48-2.86)\end{array}$ \\
\hline $\begin{aligned} \text { Family income }: & >1500 \text { euros/month } \\
& <=1500 \text { euros/month }\end{aligned}$ & 1100 & $\begin{array}{c}1 \\
2.29(1.64-3.20) \\
\end{array}$ \\
\hline $\begin{array}{r}\text { Parental separation: No } \\
\text { Yes } \\
\end{array}$ & 1094 & $\begin{array}{c}1 \\
1.59(1.03-2.44) \\
\end{array}$ \\
\hline $\begin{array}{r}\text { Number of siblings: None } \\
\qquad>=1\end{array}$ & 1113 & $\begin{array}{c}1 \\
0.65(0.47-0.90)\end{array}$ \\
\hline $\begin{array}{r}\text { Negative life events: No } \\
\text { Yes }\end{array}$ & 1111 & $\begin{array}{c}1 \\
1.62(1.15-2.28)\end{array}$ \\
\hline
\end{tabular}


Table 4. Maternal tobacco smoking in pregnancy and children's high symptoms of hyperactivity/inattention at age 5 years (EDEN mother-child birth cohort study, $n=997$, Inverse probability weights-controlled $\mathrm{ORs}, 95 \% \mathrm{Cl})^{\text {a }}$

\begin{tabular}{|l|c|}
\hline & $\begin{array}{c}\text { High symptoms of } \\
\text { hyperactivity/ } \\
\text { inattention }\end{array}$ \\
\hline Maternal tobacco smoking in pregnancy & 1 \\
Non-smoker (103/777) & $1.19(0.41-3.48)$ \\
Quit smoking prior to pregnancy (17/105) & $1.06(0.51-2.21)$ \\
Smoked during the 1st trimester of pregnancy (20/87) & $\mathbf{2 . 2 0 ( 1 . 2 1 - 4 . 0 0 )}$ \\
Smoked throughout pregnancy (36/144) & \\
\hline
\end{tabular}

\footnotetext{
${ }^{a}$ Multivariate analyses are controlled for inverse probability weights (IPW) based on children's sex, premature birth, birth weight, duration of breastfeeding, maternal age at birth, maternal psychological difficulties in pregnancy, maternal depression post-pregnancy, maternal alcohol use in pregnancy, maternal smoking post pregnancy, paternal tobacco smoking during and post pregnancy, study center, parents' educational attainment, family income, parental separation, number of siblings, negative life events.
} 